\title{
СРАВНИТЕЛЬНАЯ ОЦЕНКА РЕЖИМОВ БАЗИС-БОЛЮСНОЙ ИНСУЛИНОТЕРАПИИ И САМОКОНТРОЛЯ САХАРНОГО ДИАБЕТА 1 ТИПА У ДЕТЕЙ
}

\author{
1,2 Дианов О.А., ${ }^{1}$ Мальцев В.В., ${ }^{2}$ Анфилов И.С. \\ 'ГБУз Тверской области «Клиническая детская больница №2», Тверь \\ ${ }^{2}$ ФГБОУ ВО «Тверской государственный медицинский университет» Минздрава России, Тверь
}

ЦЕЛЬ: сравнить эффективность базис-болюсной инсулинотерапии в режиме множественных инъекций инсулина (МИИ) и режиме постоянной подкожной инфузии инсулина (ППИИ) и в зависимости от режима точечного измерения гликемии (ТИГ) и режима непрерывного мониторинга гликемии (НМГ) при самоконтроле сахарного диабета 1 типа у детей.

МАТЕРИАЛЫ И МЕТОДЫ: проведено комплексное обследование 167 детей, больных сахарным диабетом 1 типа, наблюдающихся в Эндокринологическом центре ГБУЗ Тверской области «Клиническая детская больница №2» в 2019 году. У 145 больных применялся режим МИИ (средний возраст 12士2,6 лет,

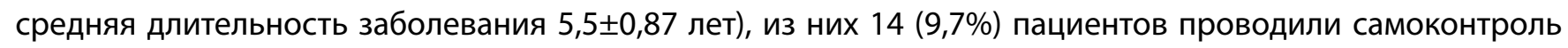

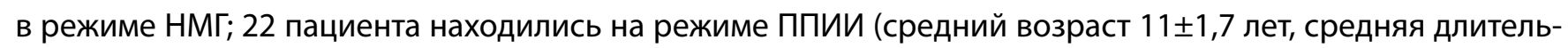

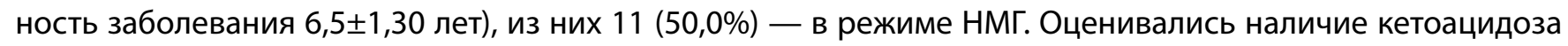
и/или гипогликемий, суточную потребность в инсулине, уровень гликированного гемоглобина (НbА ${ }_{1 c}$ ), наличие микроальбуминурии (МАУ), диабетических нейро- и ретинопатии, показатели липидного спектра крови.

РЕзУЛЬтАТЫ: в группе детей на режиме МИИ частота кетоацидоза и/или гипогликемий составила 67 случаев (36,8\%). В группе детей, находящихся на режиме ППИИ, встречаемость кетоацидоза и/или гипогликемий составила 4 случая (8,5\%, p<0,01). Средняя потребность в инсулине у детей на режиме МИИ соста-

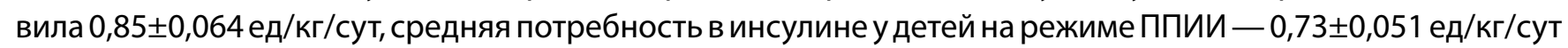

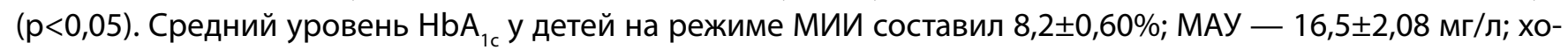

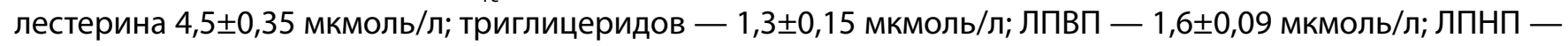

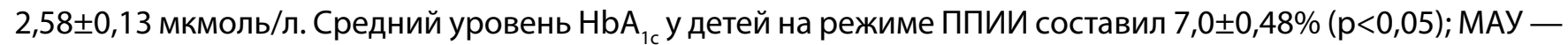

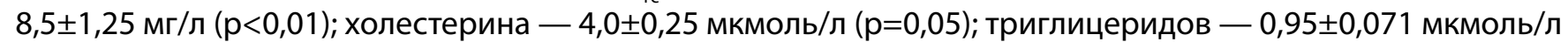

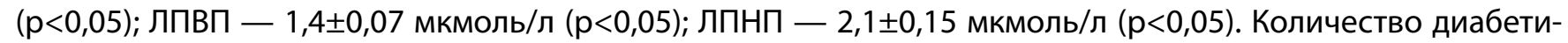
ческих нейро- и ретинопатий в группе детей на режиме МИИ составило 15 (10,3\%) и 10 (6,9\%), а в группе детей на режиме ППИИ - $1(4,5 \% ; p<0,05)$ и $1(4,5 ; p=0,05)$ соответственно. Отмечалась уменьшение

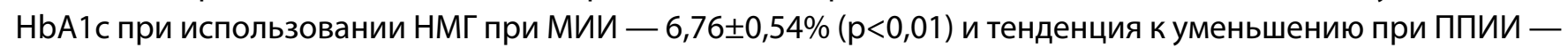
6,75 $\pm 0,31 \%(p=0,05)$ по сравнению с детьми, проводящих самоконтроль в режиме ТИГ.

Выводы: меньшая частота кетоацидоза и/или гипогликемий, меньшая потребность в суточном количестве инсулина, более стойкая компенсация, отсутствие гипер/дислипидемий и микроальбуминурии, а также меньшее количество диабетических осложнений, указывают на лучшую эффективность режима постоянной подкожной инфузии инсулина по сравнению с режимом множественных инъекций инсулина при базис-болюсной инсулинотерапии, а использование непрерывного мониторинга гликемии при самоконтроле улучшает метаболический контроль сахарного диабета 1 типа у детей.

КЛЮЧЕВЫЕ СЛОВА: сахарный диабет 1 mипа; базис-болюсная инсулинотерапия, самоконтроль гликемии, дети. 